\title{
Remobilisation of uranium from contaminated freshwater sediments by bioturbation
}

\author{
S. Lagauzère ${ }^{1}$, M. Motelica-Heino ${ }^{2}$, E. Viollier ${ }^{3}$, G. Stora ${ }^{4}$, and J. M. Bonzom ${ }^{1}$ \\ ${ }^{1}$ Laboratoire d'Ecotoxicologie des Radionucléides, Institut de Radioprotection et de Sûreté Nucléaire \\ (IRSN)/PRP-ENV/SERIS, Cadarache, Bât. 186 - BP 3, 13115 Saint-Paul-Lez-Durance, France \\ ${ }^{2}$ Université d'Orléans, ISTO, UMR7327 CNRS/INSU 1A, rue de la Férollerie, 41071 Orléans Cedex 02, France \\ ${ }^{3}$ Laboratoire de Géochimie des Eaux, Université Paris Diderot, Sorbonne Paris Cité, Institut de Physique du Globe de Paris, \\ UMR7154 CNRS, 75013 Paris, France \\ ${ }^{4}$ Université Aix-Marseille, CNRS/INSU, IRD, Mediterranean Institute of Oceanography (MIO), UM110, \\ 13288 Marseille, France
}

Correspondence to: S. Lagauzère (lagauzere@gmail.com)

Received: 25 September 2013 - Published in Biogeosciences Discuss.: 30 October 2013

Revised: 19 March 2014 - Accepted: 20 May 2014 - Published: 25 June 2014

\begin{abstract}
Benthic macro-invertebrate bioturbation can influence the remobilisation of uranium (U) initially associated with freshwater sediments, resulting in a high release of this pollutant through the overlying water column. Given the potential negative effects on aquatic biocenosis and the global ecological risk, it appears crucial to improve our current knowledge concerning the biogeochemical behaviour of $\mathrm{U}$ in sediments. The present study aimed to assess the biogeochemical modifications induced by Tubifex tubifex (Annelida, Clitellata, Tubificidae) bioturbation within the sediment in order to explain such a release of U. To reach this goal, $\mathrm{U}$ distribution between solid and solute phases of a reconstructed benthic system (i.e. in mesocosms) inhabited or not by $T$. tubifex worms was assessed in a 12-day laboratory experiment. Thanks notably to fine-resolution (mm-scale) measurements (e.g. "diffusive equilibrium in thin-films" DET gel probes for porewater, bioaccumulation in worms) of $U$ and main chemical species (iron, sulfate, nitrate and nitrite), this work (i) confirmed that the removal of bottom sediment particles to the surface through the digestive tract of worms greatly favoured oxidative loss of $U$ in the water column, and (ii) demonstrated that both $\mathrm{U}$ contamination and bioturbation of T. tubifex substantially influenced major microbial-driven biogeochemical reactions in sediments (e.g. stimulation of denitrification, sulfate reduction and iron dissolutive reduction). This study provides the first demonstration of biogeo-
\end{abstract}

chemical modifications induced by bioturbation in freshwater U-contaminated sediments.

\section{Introduction}

Trace metal pollution of rivers, lakes and estuaries is a serious ecological problem in many industrialised areas worldwide. Despite recent efforts to improve water quality, notably in most developed countries, many aquatic ecosystems are still threatened by pollution accumulated in sediments and groundwater. In this context, the case of uranium (U) released by mining extraction is of particular interest due to its complex biogeochemical behaviour and its potentially high ecotoxic risk for aquatic biocenosis. Whereas the natural geochemical background level of $U$ in freshwater sediments is considered to be $<10 \mu \mathrm{g} \mathrm{Ug}^{-1}$ (dry weight) (Kurnaz et al., 2007), much higher concentrations, up to several $\mathrm{mg} \mathrm{Ug}^{-1}$, have been measured in rivers and lakes close to former or operating mining sites (Neame et al., 1982; Hart et al., 1986; Lozano et al., 2002; Lottermoser and Ashley, 2006). The long-term storage capacity of such contaminated sediments depends on numerous geochemical and biological parameters affecting the solubility and thus the mobility of $U$.

The biogeochemical behaviour of $U$ in surface sediments is directly related to its speciation, the chemistry of the solute and solid phases and to processes including precipitation, 
dissolution, adsorption, complexation and to a large extent numerous transformations during early diagenesis processes. $\mathrm{U}$ speciation is primarily related to $\mathrm{pH}$ and oxido-reduction potential values (Langmuir, 1978) but also strongly depends on $\mathrm{CO}_{2}$ partial pressure, the ionic force of solute phases, the total concentration of $\mathrm{U}$, the presence of organic and mineral ligands (Ragnarsdottir and Charlet, 2000; Davis et al., 2002, 2004, 2006; Denison, 2004; Curtis et al., 2006), and microbial activity (Renshaw et al., 2007). In most surface freshwater (i.e. under oxic conditions, $\mathrm{pH} 5-9$ ), $\mathrm{U}$ is in a free and soluble form, the uranyl ion $\mathrm{UO}_{2}^{2+}$, which is in the (+VI) oxidation state. Depending on the $\mathrm{pH}$ and ionic composition of the water, $\mathrm{UO}_{2}^{2+}$ can form complexes with other ions, principally hydroxyls or carbonates, phosphates, fluorides, chlorides, but also with some organic compounds such as humic acids (Ragnarsdottir and Charlet, 2000; Marang, 2007). Adsorption on mineral (e.g. oxy/hydroxides of iron or manganese and clays) or organic particulate phases also plays an important role by reducing $\mathrm{UO}_{2}^{2+}$ mobility in water (Curtis et al., 2006). Thus, $\mathrm{U}$ coming into contact with sediment is either in soluble form (free or complexed) and will diffuse towards the porewater, or be sorbed to suspended matter and incorporated by sedimentation. In anoxic sediments, $\mathrm{U}$ is reduced to insoluble $\mathrm{U}(+\mathrm{IV})$ and tends to be immobilised and thus accumulates in the deeper sediment layers by formation of insoluble nanoparticulates or large aggregated oxides like uraninite or schoepite (Liger et al., 1999; Phrommavanh, 2008). Additionally, reduction of $U$ can also occur biotically through metal-reducing bacterial metabolism in sediment (Lovley et al., 1991). This process has notably been used in recent bioremediation programs of contaminated sites where immobilisation of $U$ in sediments was favoured by organic amendment at the sediment surface (Wall and Krumholz, 2006; Wilkins et al., 2006; Renshaw et al., 2007; Barlett et al., 2012).

Inversely, mechanical disturbances of upper sediment can hamper the incorporation of $\mathrm{U}$ into anoxic bottom layers and its immobilisation. Among them, modifications of sediment properties induced by benthic macro-invertebrate activities (i.e. bioturbation) are likely to be of most importance. As demonstrated for diverse trace metals, bioturbation can increase their remobilisation from the sediment through the overlying water by favouring the oxidative loss of previously accumulated solid phases (Motelica-Heino et al., 2003; Naylor et al., 2004, 2006, 2012). Three major processes are involved: (i) oxygen penetration in bottom sediment due to active water pumping in burrows (i.e. bioirrigation); (ii) removal of particles from the bottom sediment to its surface; and (iii) and indirect effects due to induced heterogeneity (e.g. redox conditions, organic matter availability and fluxes of solutes) and stimulation/inhibition of microbial communities. However, little work has been undertaken to evaluate these processes in sediments accumulating $\mathrm{U}$ in freshwater systems (Komlos et al., 2008; Phrommavanh, 2008) and the few previous studies on this topic have concerned ma- rine ecosystems (Zheng et al., 2002; Morford et al., 2009). In freshwater, some organisms able to survive in contaminated environments, such as tubificid worms (Annelida, Clitellata, Tubificidae), are known to induce a strong sediment reworking that could impact the remobilisation of metals (Soster et al., 1992; Petersen et al., 1995; Zoumis et al., 2001; AlfaroDe-la-Torre and Tessier, 2002; Zheng et al., 2002; Ciutat and Boudou, 2003; De Haas et al., 2005; Ciutat et al., 2007). Tubificid worms represent a dominant group of freshwater benthic macro-invertebrates. Their populations can reach very high densities, notably in organic-rich sediments. Despite no active bioirrigation of their gallery network, the effects induced by tubificid worms on the sediment matrix are crucial for global biogeochemical functioning and the metal distribution at the benthic interface. Due to their particular mode of feeding which consists of ingestion of sediment particles in bottom layers and rejection at the sedimentwater interface (i.e. upward-bioconveying, sensu Gérino et al., 2003), they create a removal of associated compounds including metals initially immobilised in reduced forms. This phenomenon was recently observed in U-contaminated sediment inhabited by Tubifex tubifex worms (Lagauzère et al., $2009 \mathrm{a}, \mathrm{b}, \mathrm{c})$. In these mesocosm experiments, it was demonstrated that despite important ecotoxic effects of $U$ on the worms (e.g. malformations, autotomy and mortality), their bioturbation activity remained sufficiently important to stimulate diagenetic processes (e.g. increase of oxygen uptake) and to induce a 2- to 10-fold higher release of $U$ through the overlying water. However, underlying biogeochemical processes occurring under these conditions still need to be assessed to explain the remobilisation of $\mathrm{U}$.

The main goal of this study was to assess the influence of the bioturbation of T. tubifex in a benthic ecosystem for which sediment was initially contaminated with U. We conducted a laboratory experiment using mesocosms with natural sediment artificially contaminated with $U$ and inhabited or not by T. tubifex. The distribution of $\mathrm{U}$ between solid and solute phases, including bioaccumulation in T. tubifex worms, was estimated to calculate fluxes between the sediment and the water column, and a mass budget. In parallel, high-resolution profiles of dissolved $U$, iron, manganese, sulfates, nitrates and nitrites were measured to give an overview of the main biogeochemical reactions occurring in sediment and to propose hypotheses of their interactions with $\mathrm{U}$ in the presence or absence of T. tubifex worms.

\section{Material and methods}

\subsection{Preparation of aquaria}

Surface sediment and water were collected in the Esparron Lake, a reservoir lake upstream from a manmade dam on the river Verdon (Alpes de Haute-Provence, southern France). This site was chosen for the pristine quality of its surface 
water and the fine texture of the sediment (median grain size, $D_{50}=33.8 \mu \mathrm{m}$ ). Sediments were treated to eliminate the coarse particulate phases (vegetal fragments, stones and wastes) and large organisms by sieving at $2 \mathrm{~mm}$ and freezing at $-20^{\circ} \mathrm{C}$ for $48 \mathrm{~h}$. The sediments were then homogenised mechanically and stored at $4{ }^{\circ} \mathrm{C}$ until preparation of the aquaria. The water was filtered at $20 \mu \mathrm{m}$ to eliminate macrofauna and meiofauna and also stored at $4{ }^{\circ} \mathrm{C}$ before use. The principal physical and chemical parameters of the sediment and overlying water were reported previously (Lagauzère et al., 2009c). Briefly, analyses revealed a highly calcareous medium (total calcite in sediments of $70 \%$ and water hardness of $152 \mathrm{Eq} \mathrm{mg} \mathrm{CaCO} \mathrm{L}^{-1}$ ) with $\mathrm{pH}$ of 8.2-8.6 and low organic matter content $(2.4 \%)$ for lacustrial sediment.

The sediment was artificially contaminated with a solution of uranyl nitrate $\left[\mathrm{UO}_{2}\left(\mathrm{NO}_{3}\right)_{2} \cdot 6 \mathrm{H}_{2} \mathrm{O}\right]$ in a large HDPE container $\left(68 \mathrm{~L}\right.$ drum from $\mathrm{CurTec}^{\circledR}$, the Netherlands; with height $=65 \mathrm{~cm}$ and $\emptyset=41 \mathrm{~cm}$ ) to obtain a nominal U concentration of $600 \mu \mathrm{g} \mathrm{U} \mathrm{g}^{-1}$ (dry weight). The tank was then shaken daily for two weeks before the beginning of the experiment to allow adsorption of $U$ on the sediment particles and homogenous contamination. The effective measured concentration after two weeks was $539 \mu \mathrm{g} \mathrm{U} \mathrm{g}{ }^{-1}$. This concentration level was chosen as a function of previous results with similar experimental conditions - although corresponding to a significantly diminished bioturbation activity, it generates important remobilisation of $U$ from the sediment to the water column (Lagauzère et al., 2009a, c). A non-contaminated sediment tank was similarly prepared for control aquaria. For each condition (contaminated and control), nine aquaria were prepared in cylindrical PVC boxes $(12 \mathrm{~cm}$ diameter and $20 \mathrm{~cm}$ height). The aquaria were filled with $10 \mathrm{~cm}$ of sediment and an overlying $10 \mathrm{~cm}$ water column. They were randomly placed in a large tank with controlled temperature $\left(21^{\circ} \mathrm{C}\right)$ and photoperiod $(16 \mathrm{~h} \mathrm{light} / 8 \mathrm{~h}$ dark). Each aquarium received constant air bubbling in the water column. This setting was equilibrated for four weeks before introduction of $T$. tubifex worms. There were slight daily additions of distilled water to compensate for water losses due to evaporation. Volumes extracted for sampling were replaced by initial lake water.

\subsection{Origin, acclimatization and introduction of benthic organisms}

The T. tubifex worms were purchased from a commercial breeder (Grebyl and Fils, Arry, France). They were acclimated to the experimental conditions for 10 weeks and fed twice weekly with Tetramin ${ }^{\circledR}$ flakes (Tetra Werke, Melle, Germany) in a suspension $\left(3 \mathrm{mg}\right.$ ind $^{-1}$ from a $10 \mathrm{gL}^{-1}$ suspension). Before the beginning of the experiment, the worms were starved in artificial sand for $48 \mathrm{~h}$. In each aquarium devoted to worm addition, $28 \mathrm{~g}$ of $T$. tubifex were added at the sediment surface. This mass corresponds to ca. $60000 \mathrm{ind} \mathrm{m}^{-2}$, representing an average natural density for freshwater ecosystems (Budd, 2005). The air bubbling was stopped for $3 \mathrm{~h}$ to allow the worms to settle at the sedimentwater interface.

\subsection{Experimental procedure}

Of the nine aquaria prepared for each condition (i.e. contaminated and control), three were retrieved on the first day of the experiment (day 0), i.e. after the four weeks of stabilisation; three received T. tubifex worms at day 0 and were retrieved after 12 days; and the remaining three did not receive any organisms and were also retrieved at day 12 . The coding of experimental treatments was as follows: C- for control, $\mathrm{U}$ - for contaminated sediment and $\mathrm{T}$ - for the presence of $T$. tubifex, followed by -0 or -12 for the time of sampling (e.g. UT-12 corresponds to a "contaminated sediment/presence of worms" after 12 days).

\subsection{Physico-chemical measurements}

\subsubsection{Measurements in the water column: temporal monitoring}

Temperature, $\mathrm{pH}$ and dissolved oxygen concentration of the water column were measured one day before the introduction of T. tubifex worms and then every second day until the end of the experiment (day 12). The concentration in total $U$ in the water column was monitored from $10 \mathrm{~mL}$ non-filtered and acidified water samples $\left(2 \% \mathrm{HNO}_{3}\right)$ analysed by ICPAES (Optima 4300 DV, Perkin Elmer, USA). The apparent $\mathrm{U}$ exchange flux between the sediment and the water column was calculated from $U$ concentrations at day 0 and day 12 (based on the variation of $\mathrm{U}$ in the water column divided by the area of the water-sediment interface). The concentrations of dissolved chemical species, including $U$, were estimated from the average values measured from the water-exposed part of the DET probe (see below). The differences in concentrations between day 12 and day 0 were also expressed as mean fluxes.

\subsubsection{Porewater concentration profiles of dissolved chemical species}

In each aquarium, the concentration profiles of the dissolved elements were determined by using two constrained DET (diffusive equilibrium in thin films) probes purchased from DGT Research Ltd (Lancaster, UK, www.dgtresearch.com). One of the probes was devoted to the analysis of major cations and U by ICP-AES (Optima 4300 DV), whereas the second one was used for analysis of major anions by ionic liquid chromatography (DX120, column AS11HC $4 \mathrm{~mm}$, eluant $\mathrm{KOH}$, Dionex, Sunnyvale, USA). These peeper-gel probes consisted of plastic holders $(240 \times 40 \times 5 \mathrm{~mm})$ with an open window $(18 \times 150 \mathrm{~mm})$. From the aperture, a series of parallel agarose-gel strips $(1 \times 1 \times 18 \mathrm{~mm})$ were exposed through a $0.2 \mu$ m nylon membrane to the ambient medium for 
equilibration. Before use, the probes were deoxygenised in a $0.01 \mathrm{M} \mathrm{NaCl}$ solution with bubbled nitrogen for $48 \mathrm{~h}$. They were afterwards deployed in the sediment of each aquarium $48 \mathrm{~h}$ before the desired analysis time (i.e. 2 days before introduction of the organisms for treatments $\mathrm{C}-0$ and $\mathrm{U}-0$ and at day 10 for treatments C-12, CT-12, U-12 and UT-12). After sampling, the probes were placed in a glove box under a nitrogen atmosphere. The gel strips were gently retrieved and directly eluted in $1 \mathrm{~mL}$ of $2 \% \mathrm{HNO}_{3}$ for samples analysed by ICP-AES (major cations and U) and in $1 \mathrm{~mL}$ of Milli-Q water for samples analysed by ionic chromatography (major anions). All measurements were performed in the 6 days following the sampling. During their storage, the samples were kept at $4{ }^{\circ} \mathrm{C}$ and hand-shaken daily. Calculations were made based on the assumption of gel strip dimensional homogeneity.

\subsubsection{Determination of net accumulation rates in overlying water}

Accumulation rates were calculated from differences between start-end concentrations of dissolved species divided by the experimental duration. Positive values indicate a net input to the overlying water, and in contrast, negative values indicated net elimination/output of dissolved species.

\subsubsection{Determination of diffusive instantaneous fluxes at the sediment-water interface and sediment $U$ consumption rates}

Each vertical profile of dissolved chemical species was simulated using PROFILE software (Berg et al., 1998) in order to estimate $\mathrm{U}$ consumption rates below the sediment-water interface and instantaneous diffusive fluxes of other solutes.

Briefly, the diffusive flux $J$ at the sediment-water interface was estimated from the sediment porewater concentration profile obtained with the DET probe using Fick's first law of diffusion (Li and Gregory, 1974; Berner, 1980):

$J(z)=-\phi \cdot D_{\mathrm{s}} \cdot \frac{\partial C(z)}{\partial z}$,

where $\varphi$ is porosity, $D_{\mathrm{S}}$ is the diffusion coefficient in sediments $\left(\mathrm{cm}^{2} \mathrm{~s}^{-1}\right), C$ is the concentration $\left(\mathrm{mmol} \mathrm{cm}^{-3}\right), z$ is the depth $(\mathrm{cm})$ and $C(z) / z$ is the concentration gradient across the sediment-water interface.

$D_{\mathrm{S}}$ was estimated from values of the diffusion coefficient in water $D$ reported in the literature, corrected for temperature and salinity (Li and Gregory, 1974; Boudreau, 1997; Schultz and Zabel, 2000) and the tortuosity $\theta$ of the sediment using the following equation:

$D_{\mathrm{s}}=\frac{D}{\theta^{2}}$,

where $\theta$ was calculated from $\varphi$ using the empirical relationship given by Boudreau (1997):

$\theta^{2}=1-\ln \left(\phi^{2}\right)$.
In our experiments the subsurface porosity was estimated at 0.75 in the absence of worms and 0.83 in the presence of worms, independently of $\mathrm{U}$ contamination (Lagauzère et al., 2009a). Thus there was $\theta^{2}=1.57$ without worms (treatments C-0, C-12, U- 0 and U-12), and $\theta^{2}=1.37$ with worms (CT- 0 , CT-12, UT-0 and UT-12).

Differential equations were then solved numerically at a steady state to reproduce $C(z)$ and provide the best "reasonable" estimation of $J(z)$ (Berg et al., 1998). The boundary conditions were the concentration in the overlying water at the top and an absence of flux in deeper sediment. All fluxes were integrated over overlying water height in order to be compared to net accumulation rates in overlying water.

\subsubsection{Determination of $U$ concentration in the solid phase of sediment}

After the aforementioned analyses, at day 0 for $\mathrm{C}-0$ and $\mathrm{U}-0$, and at day 12 for C-12, CT-12, U-12 and UT-12, the overlying water was retrieved with a syringe and the sediment column was gently sliced into $1 \mathrm{~cm}$ slices. Each slice was dried at $60^{\circ} \mathrm{C}$ for $72 \mathrm{~h}$ and then homogenised by manual grinding with a mortar. Three sub-samples of $1 \mathrm{~g}$ of dry sediment were then mineralised by successive addition of $\mathrm{HNO}_{3}, \mathrm{HCl}$ and $\mathrm{H}_{2} \mathrm{O}_{2}$. After two cycles of mineralisation/evaporation $\left(105^{\circ} \mathrm{C}\right.$ for $\left.90 \mathrm{~min}\right)$ the solutions were filtered at $0.45 \mu \mathrm{m}$ (Minisart acetate cellulose filters) and subsequently analysed by ICP-AES to determine the concentration of total $U$ in the sediment. These data were used to calculate the global mass budget of $U$ over the entire experiment.

\subsubsection{Determination of $\mathrm{U}$ bioaccumulation in T. tubifex worms}

Four hours before dismantling the contaminated aquaria containing T. tubifex worms (UT-12) the air bubbling was stopped and each unit was placed in a bain-marie $\left(25^{\circ} \mathrm{C}\right.$ for 5-10 min) to allow the worms to come out of the sediment. A sample of worms was rapidly collected with a pipette to determine the bioaccumulation of $\mathrm{U}$. After $2 \mathrm{~h}$ of integument depuration in non-contaminated water at ambient temperature $\left(22-25^{\circ} \mathrm{C}\right)$, samples of worms were dried at $60^{\circ} \mathrm{C}$ for $48 \mathrm{~h}$ and then mineralised with the following procedure. Each sample (ca. $630 \mathrm{mg}$ ) was mineralised by addition of $5 \mathrm{~mL}$ of $65 \% \mathrm{HNO}_{3}$ and $5 \mathrm{~mL}$ of $30 \% \mathrm{H}_{2} \mathrm{O}_{2}$ followed by two cycles of heating at $95^{\circ} \mathrm{C}$ for $90 \mathrm{~min}$. After complete evaporation, the solid residues were suspended in $10 \mathrm{~mL}$ of $2 \% \mathrm{HNO}_{3}$ at ambient temperature for $24 \mathrm{~h}$. Samples were then filtered at $0.45 \mu \mathrm{m}$ (Minisart acetate cellulose filters) and analysed by ICP-AES. The quality control sample was prepared by adding a known concentration of $\mathrm{U}$ to mineralised $T$. tubifex worms - this preparation was necessary because no certified biological material was available for U measurement by ICPAES in aquatic organisms. To estimate the amount of $U$ in the total biomass the measured concentration was related to the 


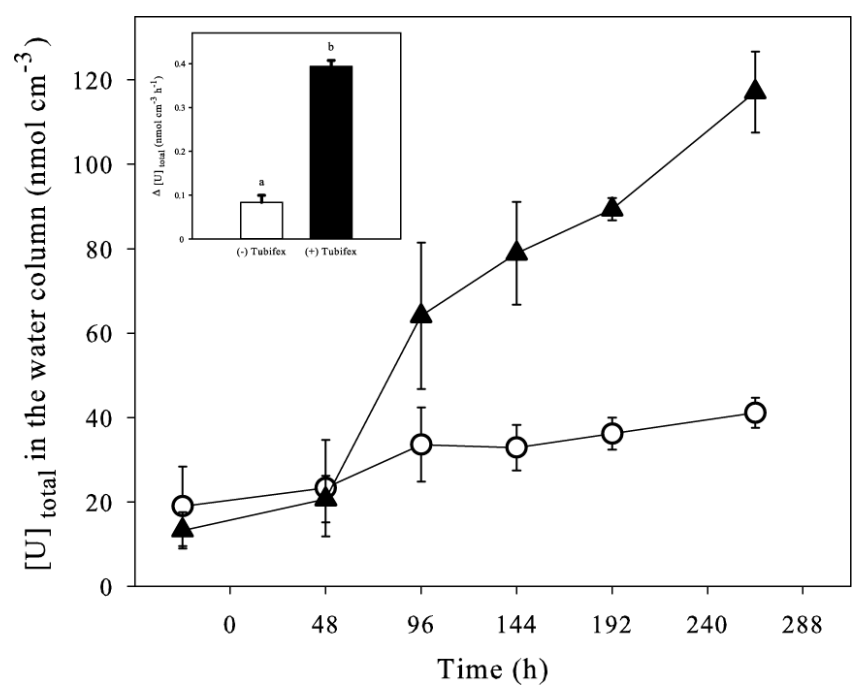

Figure 1. Temporal variation of total $U$ concentration in the water column, without $(\bigcirc)$ and with $(\boldsymbol{\Delta})$ T. tubifex worms inhabiting the sediment. The inset bar chart shows the net accumulation rate of $\mathrm{U}$ after $288 \mathrm{~h}$ (12 days). Means $\pm \mathrm{SD}(N=3)$. The data corresponding to control (i.e. uncontaminated) treatments are not plotted (concentrations below the detection limit).

mass of worms initially introduced in the aquaria with an adjustment of $-10 \%$ to account for the mortality of the species at this U concentration (Lagauzère et al., 2009c). Since U was not detected in water column, porewater or sediment from control aquaria (see below), there was no measurement of $\mathrm{U}$ bioaccumulation performed in T. tubifex coming from these treatments.

\subsection{Statistical analysis}

All statistical analyses were performed with Statistica software (StatSoft Inc., OK, USA). Before each statistical analysis, the normality of the data was tested with the ShapiroWilk test and the homogeneity of the variances with Levene's test. These tests were repeated after transformation of the data when these hypotheses were not fulfilled. A $P<0.05$ threshold of significance was applied for all statistical analyses.

i. The temporal variation of physico-chemical parameters of the water column was analysed by repeated-measures ANOVAs (RM-ANOVAs) for each treatment (i.e. sampling times: at days $-1,2,4,6,8$ and 11).

ii. The variation of total $U$ concentration in the water was analysed by a Student's $t$ test comparing treatments without and with worms (difference between U-0 and U-12 or UT-12, respectively). To separate the effects of bioturbation and $\mathrm{U}$ contamination, the variations of other parameters (iron, sulfates, nitrates and nitrites) were analysed by two-way ANOVAs
("Tubifex"/ "uranium") completed by post hoc Bonferroni tests.

iii. The diffusive fluxes at the sediment-water interface in the different treatments were analysed by one-way ANOVAs and compared by Bonferroni tests.

\section{Results}

\subsection{Chemistry of the water column}

For all experimental treatments, the water temperature was maintained at $21.2 \pm 0.1^{\circ} \mathrm{C}$, the dissolved oxygen concentration at $8.1 \pm 0.3 \mathrm{mg} \mathrm{L}^{-1}$ and $\mathrm{pH}$ at $8.4 \pm 0.2$, with no significant difference between the treatments and times of sampling (RM-ANOVAs: $P>0.05$; two-way ANOVAs: $P>0.05$ ).

The concentration of total $\mathrm{U}$ in the water column of contaminated aquaria, with and without T. tubifex worms, over time is presented in Fig. 1, with the apparent net accumulation rate of $U$ in the water column as an inset. In both cases, the $\mathrm{U}$ concentrations increased during the experiment but reached clearly higher values in the presence of worms in the sediment $\left(117 \pm 9.6 \mathrm{nmol} \mathrm{U} \mathrm{cm}^{-3}\right.$, i.e. $>3$ times the concentration at day 0 ). This resulted in a net accumulation rate of total U significantly higher (i.e. five times) in the presence of worms (Student's test: $t=-14.7, P<0.0001$ ). The concentration of dissolved $\mathrm{U}$ measured with DET probes (see below) showed the same results (Fig. 2a-c). U was not detected in the water column of control aquaria (Figs. 1 and 2).

Although several other compounds were effectively measured during the analyses, only total dissolved concentrations of iron, sulfate, nitrate and nitrite are presented since certain compounds (e.g. manganese, potassium and phosphates) had concentrations below the detection limits of the measurement devices (ICP-AES: $1 \mu \mathrm{g} \mathrm{L}^{-1}$, ionic chromatography and $10 \mu \mathrm{gL}^{-1}$ ), or simply provided no relevant information (e.g. chlorides and calcium).

The results were the following:

i. Iron was not detectable in the water column of any aquarium (detection limit $<1 \mu \mathrm{g} \mathrm{L}{ }^{-1}$ ) (Fig. 3a and b).

ii. Independently of $U$ contamination, the sulfate concentrations increased significantly in the water column in the presence of worms (ANOVA "Tubifex": $F_{8,1}=$ 36.7; $P<0.0001$; "uranium": $F_{8,1}=0.98 ; P=0.35$; "Tubifex / uranium": $F_{8,1}=0.85 ; P=0.38$; Bonferroni: $P<0.05)$ (Fig. $4 \mathrm{a}-\mathrm{c})$.

iii. The concentrations of nitrate in control aquaria decreased without worms but increased strongly in their presence (Fig. 5a). In contaminated aquaria, nitrate concentrations increased with time but were much greater in the presence of worms (Fig. 5b). The highest fluxes observed under the effect of bioturbation were 

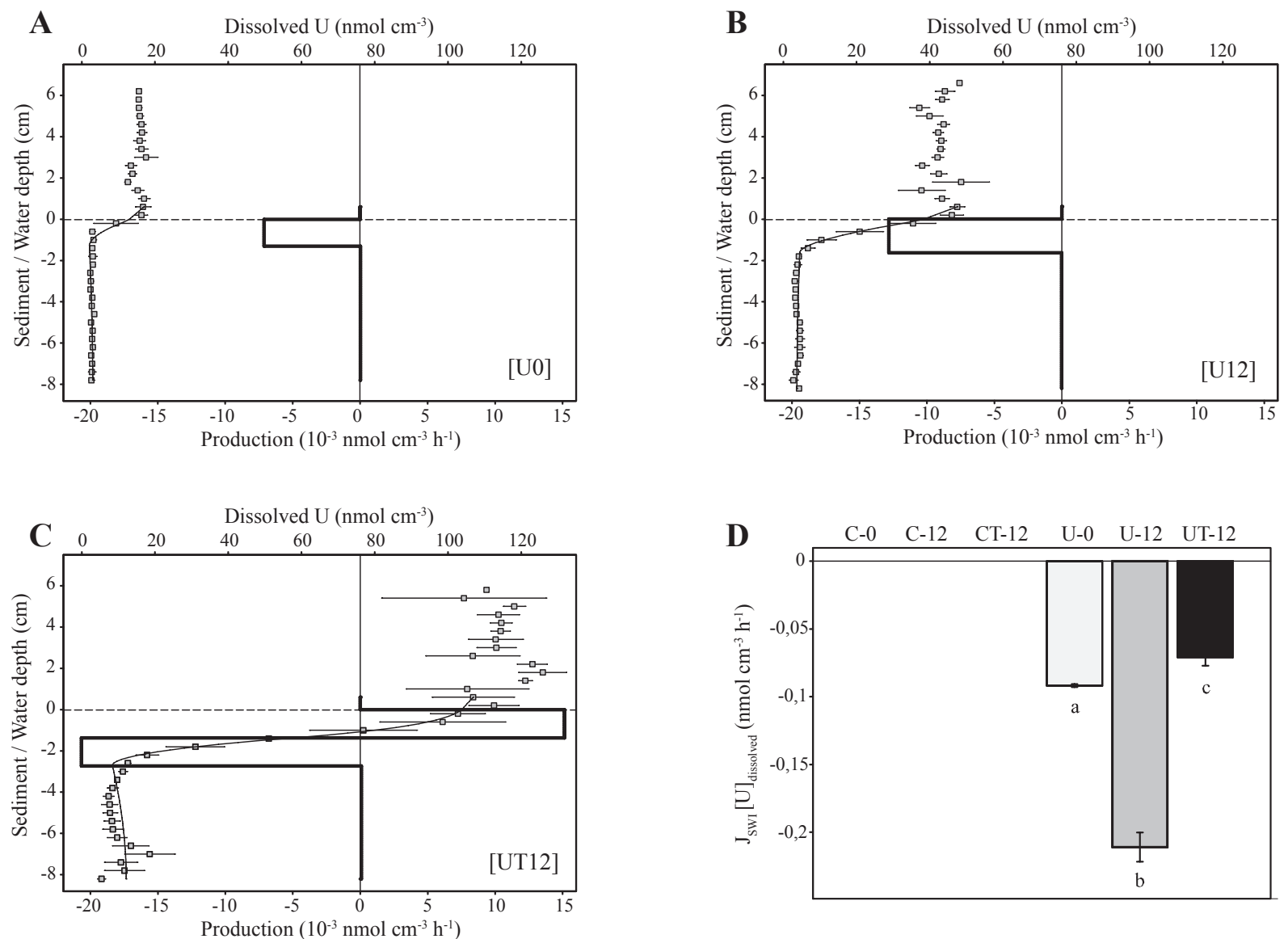

Figure 2. (A-C) Dissolved U concentration profiles and instantaneous consumption/production rates in the sediment estimated in the different treatments (at initial conditions [U-0], and after 12 days without [U-12] or with [UT-12] T. tubifex worms in the sediment) using PROFILE software. Grey dots are measured concentrations (means $\pm \mathrm{SD}, N=3$ ) and the fine black line the fitted concentration profile. The bold black line shows the production as a function of depth modelled from the concentration profile. The dotted line indicates the sedimentwater interface. (D) Diffusive downward fluxes (integrated with the height of overlying water) of dissolved U in the different treatments estimated from concentration profiles. Means $\pm \operatorname{SD}(N=3)$. Different letters correspond to significant differences between treatments. The data corresponding to control (i.e. uncontaminated) treatments - [C-O], [C-12] and [CT-12] - are not plotted (concentrations below the detection limit).

similar between control and contaminated aquaria (ANOVA "Tubifex": $F_{8,1}=482 ; P<0.0001$; "uranium": $F_{8,1}=3.85 ; \quad P<0.05$; "Tubifex / uranium": $F_{8,1}=32.8 ; \quad P<0.0001$; $\quad$ Bonferroni: $\left.\quad P<0.05\right)$ (Fig. 5c).

iv. For nitrite, despite low variations, there were slightly significant effects for bioturbation (ANOVA "Tubifex": $\left.F_{8,1}=14.22 ; \quad P<0.005\right)$ and $\mathrm{U}$ contamination (ANOVA "uranium": $F_{8,1}=223 ; \quad P<0.0001$ ) but not for the interaction of worms and $\mathrm{U}$ contamination (ANOVA "Tubifex / uranium": $F_{8,1}=0.89 ; P=0.37$ ). In the control aquaria, the nitrite concentrations diminished with time and this effect was amplified by bioturbation (Fig. 6a and c). In contrast, in the contaminated aquaria the nitrite concentrations slightly increased with time, independently of bioturbation (Bonferroni: $P<0.05$ ) (Fig. $6 \mathrm{~b}$ and $\mathrm{c}$ ).

\subsection{DET - Porewater concentration profiles}

\subsubsection{Uranium}

The water column and sediment porewater concentrations profiles of dissolved $U$ for the three contaminated treatments (U-0, U-12 and UT-12) are presented in Fig. 2a-c. In all cases, the average concentrations of $U$ determined in the water column by the DET probes were similar to those from non-filtered water samples (above-mentioned results), indicating that almost all $\mathrm{U}$ in the water column was in dissolved form. These results confirm an increase in $U$ concentrations in the water during the experiment - with a much more pronounced effect in the presence of worms. 

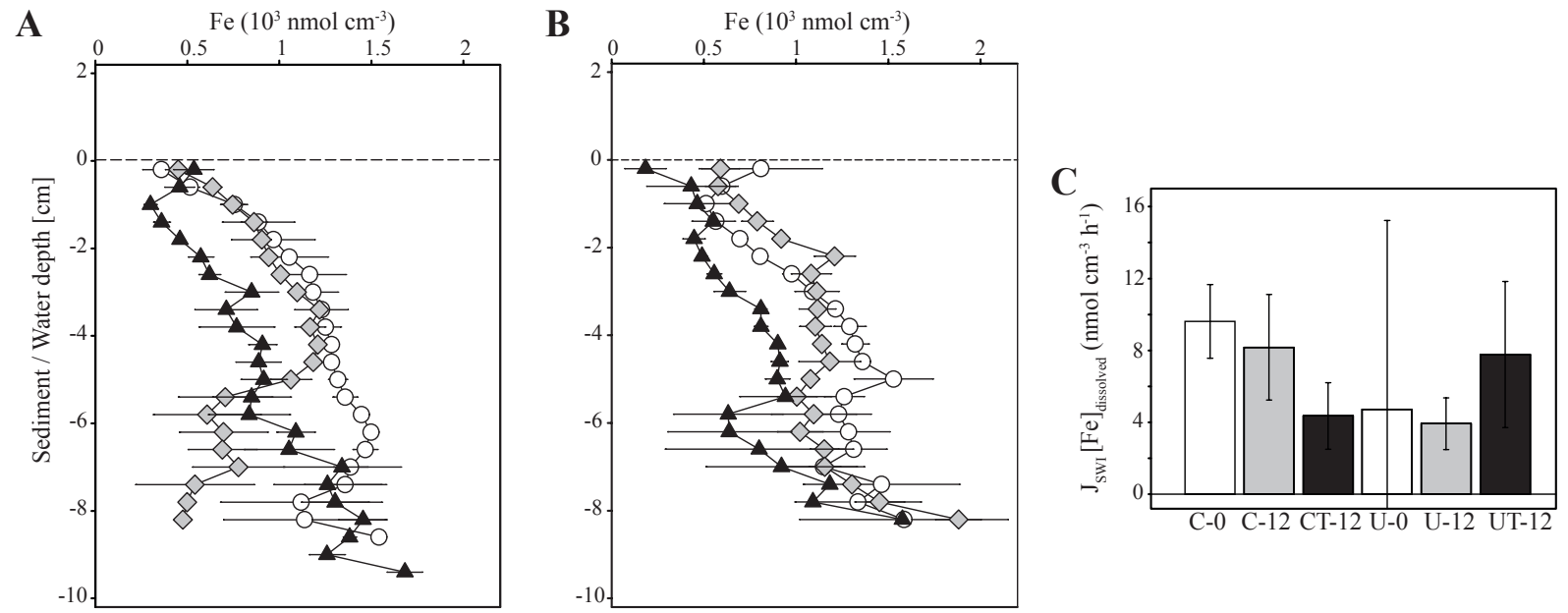

Figure 3. Dissolved total Fe concentration profiles in uncontaminated (A) and U-spiked sediment (B) in the different treatments: at initial conditions [C-0] and [U-0] (-○-), and after 12 days without [U-12] ( $\diamond)$ or with [UT-12] ( $\mathbf{\Delta})$ T. tubifex worms in the sediment. The bar chart (C) indicates the corresponding integrated outward diffusive fluxes at the sediment-water interface estimated using PROFILE software. Means $\pm \mathrm{SD}(N=3)$. No significant difference was detected between treatments.

A

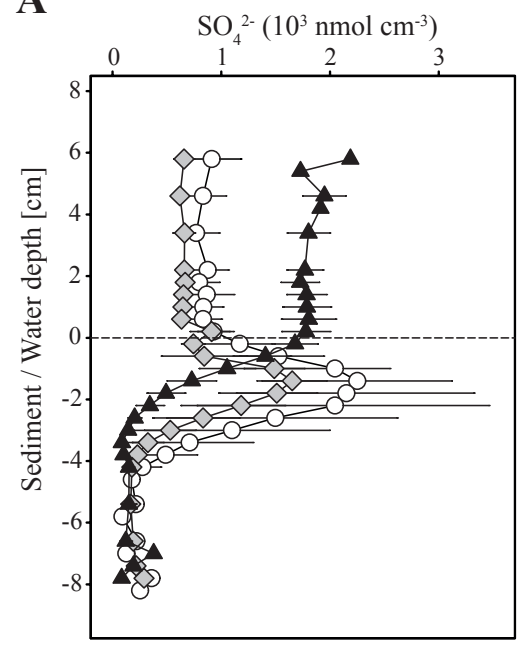

B

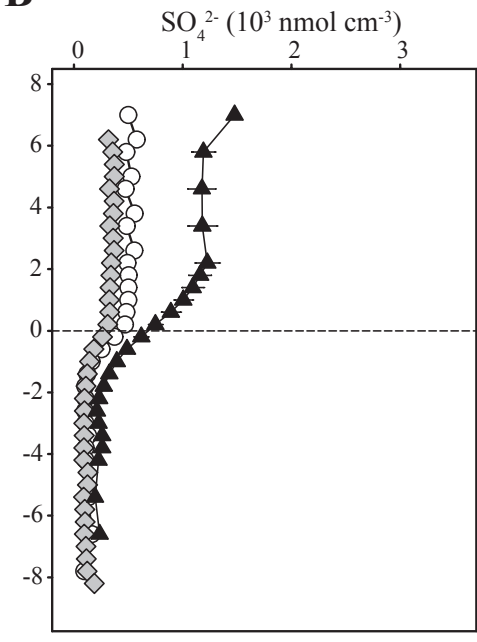

C

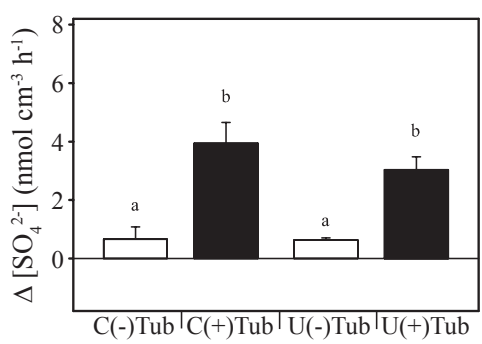

D

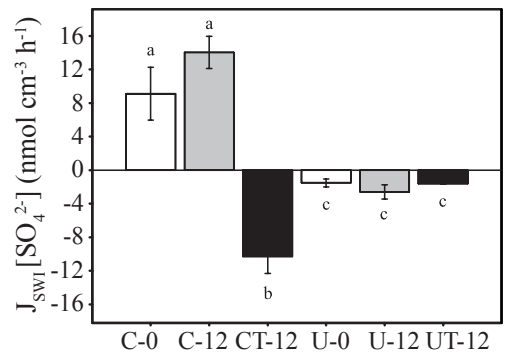

Figure 4. Dissolved sulfate concentration profiles in uncontaminated (A) and U-spiked sediment (B) in the different treatments: at initial conditions [C-0] and [U-0] ( $\bigcirc)$ and after 12 days without [U-12] ( $\diamond)$ or with [UT-12] ( $\mathbf{\Delta})$ T. tubifex worms in the sediment. The bar chart (C) corresponds to the net accumulation rate in the water column after 12 days. The bar chart (D) shows the integrated diffusive fluxes at the sediment-water interface estimated using PROFILE software. Means $\pm \operatorname{SD}(N=3)$. Different letters correspond to significant differences between treatments.

Below the sediment-water interface, the pattern of dissolved U profiles was similar for all treatments and showed decreasing concentrations with depth (Fig. 2a-c), probably due to diffusion from the overlying water and its reduction within the anoxic sediment. Modelling estimations from PROFILE revealed significant differences. On one hand, in the absence of worms, the diffusive instantaneous inward flux more than doubled with time, from $-0.09( \pm 0.00) \times 10^{-3} \mathrm{nmol} \mathrm{U} \mathrm{cm}^{-3} \mathrm{~h}^{-1}(\mathrm{U}-0)$ to -2.21
$( \pm 0.01) \times 10^{-3} \mathrm{nmol} \mathrm{U} \mathrm{cm}^{-3} \mathrm{~h}^{-1}$ (U-12). In response to increasing concentrations in overlying water and subsequently increasing chemical gradient, $U$ consumption rate increased, indicating a strong kinetic dependency on substrate (i.e. $\mathrm{UO}_{2}^{2+}$ ) concentration. On the other hand, the diffusive flux was lower with bioturbation: $-0.07( \pm 0.01) \times 10^{-3} \mathrm{nmol}$ $\mathrm{U} \mathrm{cm}^{-3} \mathrm{~h}^{-1}$. Indeed, $\mathrm{UO}_{2}^{2+}$ production occurred in a fine layer directly under the interface and the reduction started $1 \mathrm{~cm}$ deeper than in non-bioturbated sediment. This 

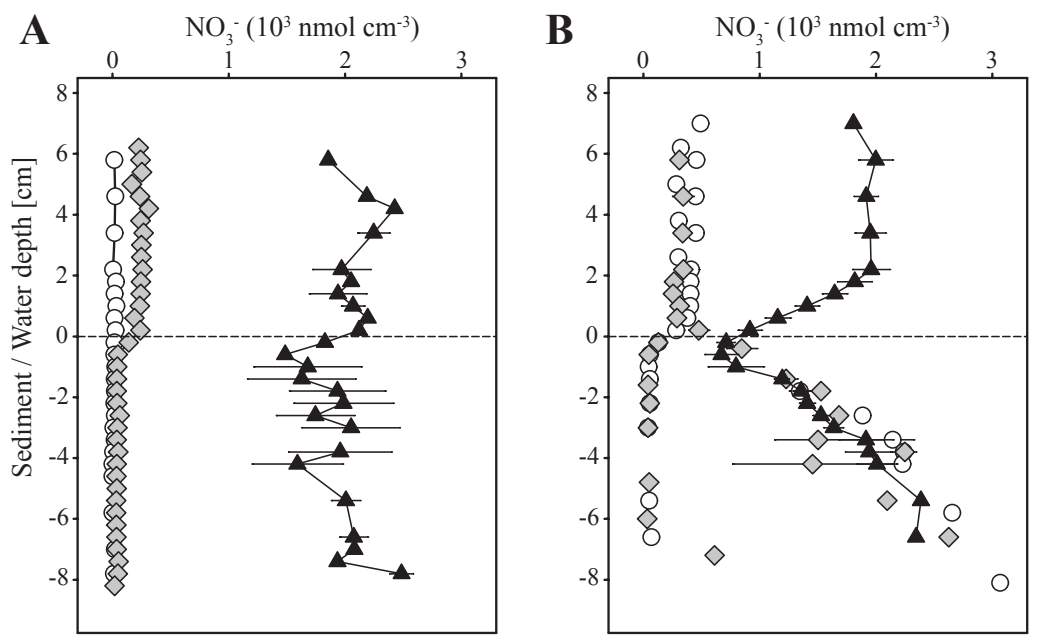

C

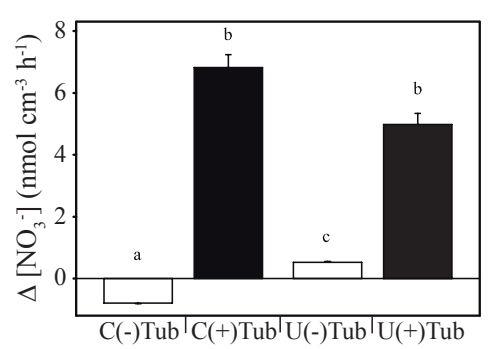

D

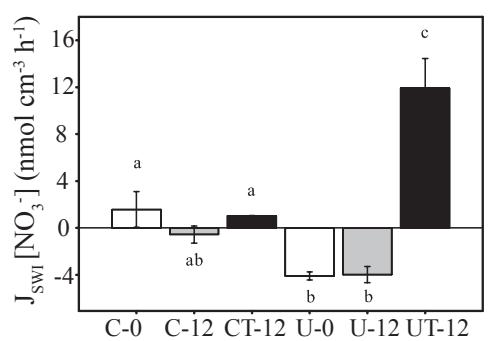

Figure 5. Dissolved nitrate concentration profiles in uncontaminated (A) and U-spiked sediment (B) in the different treatments: at initial conditions [C-0] and [U-0] ( $\bigcirc)$, and after 12 days without [U-12] ( $\diamond)$ or with [UT-12] ( $\mathbf{\Delta})$ T. tubifex worms in the sediment. The bar chart (C) corresponds to the net accumulation rates in the water column after 12 days. The bar chart (D) indicates the integrated diffusive fluxes at the sediment-water interface estimated using PROFILE software. Means $\pm \operatorname{SD}(N=3)$. Different letters correspond to significant differences between treatments.
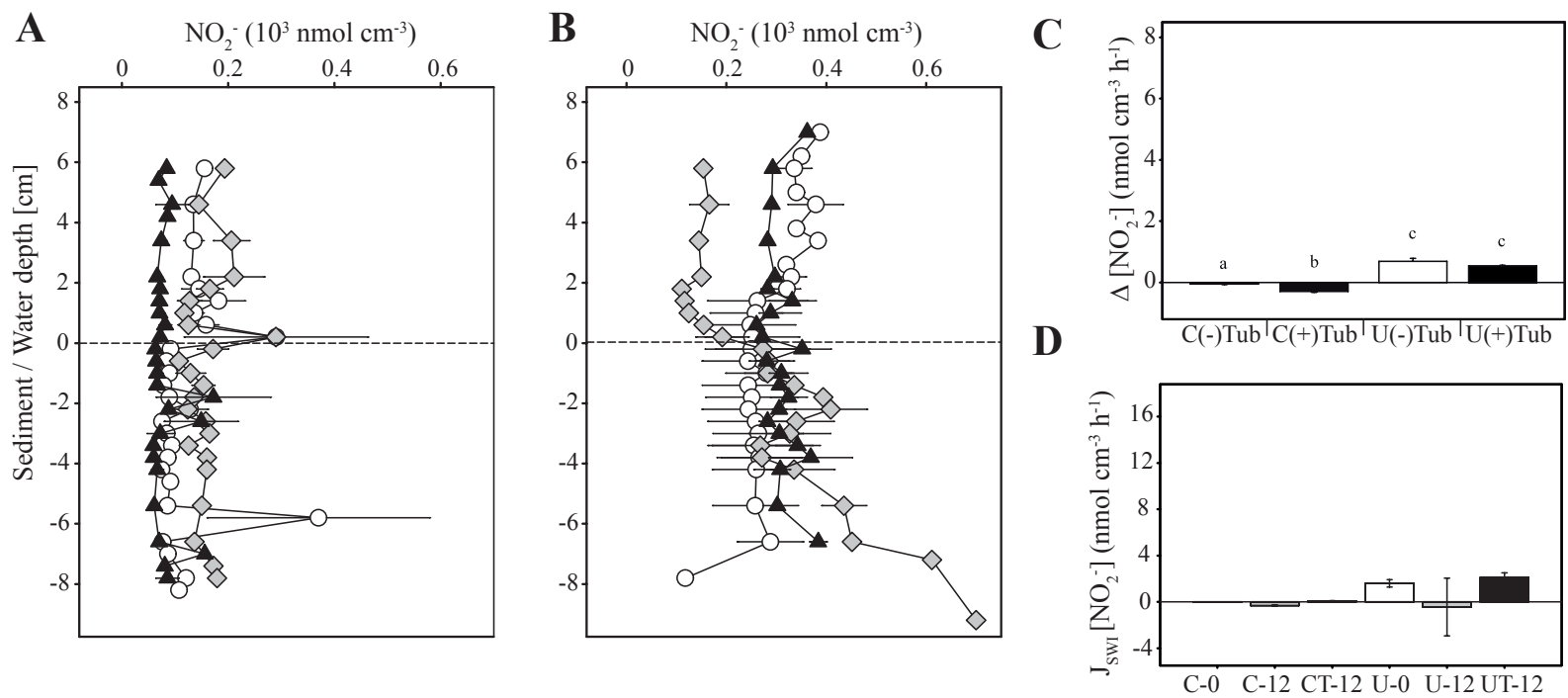

Figure 6. Dissolved nitrite concentration profiles in uncontaminated (A) and U-spiked sediment (B) in the different treatments: at initial conditions [C-0] and [U-0] ( $\bigcirc)$, and after 12 days without [U-12] $(\diamond)$ or with [UT-12] ( $\mathbf{\Delta})$ T. tubifex worms in the sediment. The bar chart (C) corresponds to the net outward flux in the water column after 12 days. The bar chart (D) indicates the corresponding diffusive fluxes at the sediment-water interface estimated using PROFILE software. Means \pm SD $(N=3)$. Different letters correspond to significant differences between treatments (no significant differences detected in $\mathbf{D}$ ).

production, accounting for $5.75 \times 10^{-5} \mathrm{nmol} \mathrm{U} \mathrm{cm}^{-2} \mathrm{~s}^{-1}$, may be relative to oxidation of upward-diffusing reduced $\mathrm{U}$ and then limited the total inward flux.

Orders of magnitude of instantaneous fluxes (Fig. 2d) and time-integrated fluxes (inset graph of Fig. 1) can be compared: they both indicate that the presence of worms clearly increased the uptake flux of $U$ as a response to increased transfer to overlying water from dissolution/release of particle-bound U. Biogeochemical pathways responsible for $U$ consumption at depth did not seem to be quantitatively modified by worm activity, at least at the experiment 
timescale. Here again, $\mathrm{U}$ was not detected on DET profiles from control aquaria.

\subsubsection{Other dissolved species}

For clarity and interest, only dissolved concentration profiles of total iron, sulfate, nitrate and nitrite are presented (Figs. 3$6)$.

Total iron - Without bioturbation (C-0 and C-12), the iron profiles showed increasing concentrations from the sediment-water interface to a certain depth and then decreased (Fig. 3a). They are characteristic of an upward diffusion of $\mathrm{Fe}^{2+}$ in upper sediment, the remobilisation of iron through dissolutive reduction of iron oxi/hydroxides in deeper sediment, and a removal by precipitation onto mineral phases within the bottom sediment. With bioturbation (CT-12), the concentrations of iron in the sediment were generally lower and decreased gradually with depth but with no peak for the profiles (Fig. 3b). The same trends were observed in contaminated aquaria (U-0, U-12 and UT-12) with an additional increase of concentrations in the deepest part of the profiles (Fig. 3b).

All profiles indicated an upward diffusive flux at the top of the sediment (Fig. 3c) although no dissolved iron was detected in the water column. This could be explained by a direct precipitation of released iron since the water was well oxygenated.

Sulfate - In the uncontaminated aquaria (C-0 and C-12), the sulfate concentration profiles showed a net production below the sediment-water interface and consumption at depth (Fig. 4a), resulting in a net outward flux towards the water (Fig. 4c). With bioturbation (CT-12), the highest concentrations were detected in the water column and sulfates diffused towards the sediment where they were directly consumed below the interface (Fig. 4d). The presence of $U$ also modified these profiles (Fig. 4b): sulfate production was not observed below the sediment-water interface in non-bioturbated (U-0 and U-12) but did occur in a fine layer in bioturbated aquaria (UT-12). Finally, sulfate consumption in bottom sediment, probably due to bacterial sulfate reduction, resulted in an inward diffusive flux in all contaminated aquaria (Fig. 4c).

Nitrate - In control aquaria without worms (C-0 and $\mathrm{C}$-12), the nitrate concentrations were low and the profiles were poorly marked (i.e. no significant flux at the sedimentwater interface), only indicating a slight consumption within sediment (Fig. 5a and d). However, the concentrations were higher in the presence of worms (CT-12) and profiles showed a slight outward diffusive flux (Fig. 5a and d). In contaminated aquaria, the profiles were clearly different. Without bioturbation (U-0 and U-12), despite some irregularities in the shape of the profiles, the nitrate concentrations gradually increased in the sediment, clearly indicating nitrate production (Fig. 5b). The resulting diffusive fluxes were directed towards the sediment (Fig. 5c and d). Here again, in the presence of worms (UT-12), concentrations were higher and the profile showed a negative peak across the sediment-water interface, reflecting nitrate consumption (Fig. 5b). However, production also occurred in this case but deeper in sediment. The net diffusive flux was directed towards the overlying water (Fig. 5d).

Nitrite - Compared to nitrate, the concentrations of nitrite were much lower. Except for the U-0 condition, for which PROFILE modelling estimated a clear production of nitrite within sediment, the other profiles indicated very slight diffusive fluxes related to consumption in non-bioturbated sediment (C-0, C-12 and U-12) and to production in bioturbated sediment (CT-12 and UT-12) (Fig. 6a-d).

\subsection{Bioaccumulation in T. tubifex worms}

The average concentration in $\mathrm{U}$ determined in the tissues of T. tubifex worms from contaminated sediment after 12 days of exposure (UT-12) was $37.4 \pm 8.3 \mu \mathrm{g} \mathrm{Ug}^{-1}$ dry weight. As the concentration of $U$ in the surrounding sediment was around ten times higher, it can be concluded that these organisms did not bioconcentrate $\mathrm{U}$, i.e. bioconcentration factor $(\mathrm{BCF}) \ll 1$. However, it should be noted that there was a low bioconcentration when comparing the value of bioaccumulation to the concentration in the water close to the sediment-water interface $(\mathrm{BCF}=1.3 \pm 0.1$ ) or to the porewater concentration in the sediment surrounding worms $(\mathrm{BCF}=2.3 \pm 0.1)$.

\subsection{Mass balance of $\mathbf{U}$}

Table 1 presents the mass balance of $\mathrm{U}$ between the different compartments (water column, sediment, porewater and organisms) for the initial conditions (day 0) and after 12 days with or without bioturbation. Although equilibrium was not reached after 12 days of experiment, since between treatments $\mathrm{U}-0$ and $\mathrm{U}-12$ the concentration in water continued to rise $(\sim 1 \%)$, the results confirmed that $\mathrm{U}$ did not remain within the sediment and was released through the water column. Bioturbation had a stronger effect on this remobilisation, with $>5 \%$ of $\mathrm{U}$ being removed from the sediment to the water phase at the end of the experiment. As remarks: (i) $\mathrm{U}$ was not detected in sediment samples coming from control aquaria, and (ii) profiles of $U$ in the solid phase of sediment are not reported (no relevant information).

\section{Discussion}

\subsection{Bioturbation effects in uncontaminated sediment}

In uncontaminated aquaria (C-0, C-12 and CT-12), the most visible consequence of bioturbation was the changes in water quality with increasing concentrations of sulfate and nitrate. Since there was no influx of water during the experiment (except for additions to compensate for evaporation and sampling), these results can only be related to changes occurring 
Table 1. Mass balance of $U$ between the different compartments of the benthic ecosystem reproduced in mesocosms. Means in \% (SD), $N=3$. The data corresponding to control (i.e. uncontaminated) treatments - [C-O], [C-12] and [CT-12] - are not reported (sediment/porewater/water column: concentrations below the detection limit; bioaccumulation: no measurement).

\begin{tabular}{lllll}
\hline & $\begin{array}{l}\text { Preparation } \\
\text { of aquaria }\end{array}$ & $\begin{array}{l}\text { Day 0 } \\
\text { U-0 }\end{array}$ & $\begin{array}{l}\text { Day 12 } \\
(-) \text { Tubifex } \\
\text { U-12 }\end{array}$ & $\begin{array}{l}\text { Day 12 } \\
\text { (+) Tubifex } \\
\text { UT-12 }\end{array}$ \\
\hline Sediment & $\sim 100$ & $99.2(0.21)$ & $98.1(0.21)$ & $95.5(0.44)$ \\
Porewater & n.a. & $0.16(0.01)$ & $0.37(0.04)$ & $0.84(0.22)$ \\
Water column & - & $0.63(0.20)$ & $1.53(0.19)$ & $4.36(0.44)$ \\
$\begin{array}{l}\text { T. tubifex worms } \\
\text { (bioaccumulation) }\end{array}$ & - & - & - & $0.13(0.06)$ \\
\hline
\end{tabular}

within the sediment. In these conditions, the worms reached the bottom of the aquaria $(10 \mathrm{~cm})$ and induced a high upward advection of sediment particles towards the water column (Lagauzère et al., 2009a, c). A fine layer of mucus-bound faecal pellets appeared at the top of the sediment. The sedimentwater interface area moderately increased, the oxygen penetration depth was reduced from 3 to $2 \mathrm{~mm}$, and the diffusive oxygen uptake (DOU) of sediment was enhanced by 14 \% (Lagauzère et al., 2009b). Previous reports have suggested that such observations are related to a global stimulation of microbial activity, notably through a supply of labile organic matter, the re-fractioning of sediment particles and the providing of new microniches for micro-organisms involved in diagenetic processes (e.g. Mermillod-Blondin et al., 2013). The upward-bioconveying of sediment particles also induces oxidation of reduced compounds removed from the bottom sediment (i.e. iron sulfide $\mathrm{Fe}-\mathrm{S}$ ), and enhances fluxes of nutrients due to higher diffusion and advection processes (Mc Call and Fisher, 1980; Matisoff, 1995; Svensson et al., 2001; Mermillod-Blondin et al., 2005; Nogaro et al., 2007). In the case of high densities of benthic worms (20000-70000 ind $\mathrm{m}^{-2}$ ), as used in the present study, Pelegri and Blackburn (1995) found that high removal of reduced compounds coupled with intensive aerobic microbial activity in the faecal pellet layer hampered oxygen penetration in surface sediments. These authors suggested that denitrification and sulfate reduction would be favoured by these suboxic/anoxic conditions, whereas nitrification would be limited to a very fine layer under the sediment-water interface. In the present work, the profiles obtained from DET-gel probes partially confirmed these assumptions. For instance, the higher sulfate concentrations measured in bioturbated aquaria (CT-12) can be explained by removal of reduced sulfur and its subsequent oxidation in the water. Sulfate ions diffuse therefore towards the sediment where they are rapidly consumed by sulfate reducers. Inversely, in non-bioturbated sediment (C-0 and C-12), the concentration profiles show a peak under the sediment-water interface that reflects production of sulfate through iron sulfide oxidation since upper sediment was more oxygenated than in bioturbated sediment. This apparent production in sediment can also be due to gyp- sum dissolution, as gypsum particles are common in the Verdon River, the main tributary of Esparron Lake (E. Viollier, personal communication, 2012). Without upward advection of sediment particles, as induced by worms (see below), the concentrations of sulfate remained low in the water column.

However, nitrate and nitrite concentration profiles do not directly fit the assumption of enhanced denitrification and limited nitrification. In all cases, the concentrations were rather homogeneous with sediment depth, indicating a lower nitrogen turnover. Nevertheless, the only remarkable profiles correspond to aquaria with bioturbation (CT-12). In these cases, concentrations were also more or less constant through the entire profile but were much higher than in non-bioturbated aquaria. As suggested by Stief and De Beer (2002), this result can be explained by a high coupling of denitrification and nitrification processes, resulting in a fast turnover of nitrogen in sediment. Through enhanced organic matter mineralisation and their own excretion, the worms lead to the production of ammonium, which is in return re-oxidized into nitrite and nitrate. The nitrate concentration profile showed, however, a low diffusion towards the sediment which could be related to consumption by denitrification.

Finally, it is important to note the downward shift in iron profiles with bioturbation, which indicated a higher dissolutive reduction of $\mathrm{Fe}$ (III)-oxi/hydroxides compared to the non-bioturbated sediment. Here again, the particle reworking of the sediment column was likely to enhance the removal of iron from bottom sediment towards a more reactive zone and then to increase its global turnover.

\subsection{Bioturbation effects in U-spiked sediment}

As already mentioned, previous experiments conducted in identical conditions have provided a solid basis for understanding the influence of T. tubifex bioturbation in U-spiked sediments and for choosing the most suitable experimental design for the present study (Lagauzère et al., 2009a, $\mathrm{b}, \mathrm{c})$. At the tested concentration of ca. $600 \mu \mathrm{g} \mathrm{Ug}^{-1}$ dry sediment (i.e. $>100$ times the background level for freshwater sediments), the population of worms was reduced by 
10-20\% after 12 days of exposure. U had several negative effects on T. tubifex (e.g. malformations, autotomy and loss of biomass) that were significant only for these high concentrations. Nevertheless, their bioturbation activity was significantly affected by this level of contamination. The most easily observable effects were a twofold reduction in the total length of the gallery network, a net concentration in upper layers of sediments $(<2 \mathrm{~cm})$, a lower maximal penetration depth $(6 \mathrm{~cm})$ and asynchronous, disordered and slower movements of sampled individuals. By simulating vertical profiles of particle tracers (microspheres and luminophores) with diagenetic models, it was possible to estimate a decrease of advective (by 60-70\%) and diffusive (by 25-30\%) transport induced by bioturbation in contaminated sediments (Lagauzère et al., 2009a). Likewise, in the presence of worms, porosity was only enhanced by $10 \%$ in the first $\mathrm{cm}$ of Uspiked sediments, while it reached $>20 \%$ within $2 \mathrm{~cm}$ in uncontaminated sediments. Finally, it is important to note that the lower penetration and dispersal of worms within the sediment column led to a twofold higher ingestion rate compared to control sediment, with a peak in the nearest $\mathrm{cm}$ immediately below the sediment surface. As a main hypothesis, it was suggested that the behaviour of worms resulted in a trade-off between avoiding contaminated sediment and yet remaining within it to meet their physiological needs and to be protected from predators.

Despite the negative effects of $\mathrm{U}$ on the activity of $T$. tubifex worms, the $\mathrm{U}$ concentration in the water column increased by five times during the course of three previous studies (Lagauzère et al., 2009a, b, c), a result confirmed in the present study. As demonstrated for other metals, such a release of $U$ can be explained by the removal of particles from anoxic layers to the surface of sediment through the digestive tract of worms. Nevertheless, underlying biogeochemical processes need to be investigated further to support this hypothesis and provide additional information on the influence of tubificid worms in contaminated sediments. Previous results relative to DOU of sediments, which is a representative parameter of the general functioning of sediment, showed a net increase due to both U contamination $(+24 \%)$, T. tubifex bioturbation $(+14 \%)$ and the combination of these two factors $(+53 \%)$. The present study confirmed and quantified the direct and indirect oxidative loss of $U$ initially associated with sediment and demonstrated a clear impact of $U$ and/or bioturbation on microbial-driven diagenetic reactions.

It is important to consider the information provided from experimental units without T. tubifex worms. As confirmed by DET profiles, $U$ released in the water was actually produced in the oxic sediment $(<3 \mathrm{~mm})$. Initially, $U$ was added to the sediment in closed containers kept without oxygenation for four weeks. In this state, most $U$ would be insoluble and in a reduced form of $\mathrm{U}(+\mathrm{IV})$. After assembling the aquaria, the sediment came into contact with aerated water and $U$ could gradually be desorbed and oxidized into its soluble form $\mathrm{U}(+\mathrm{VI})$. This result is supported by previous ex- perimental work demonstrating that oxidation of reduced $\mathrm{U}$ solid phases is rapid (Cochran et al., 1986; Anderson et al., 1989). Comparing concentrations of $U$ in the water of $U-0$ and U-12 aquaria showed that this process was still ongoing after 12 days of experiment - so equilibrium had not been reached. As a consequence, the diffusive flux of $U$ towards the sediment increased during the experiment due to increasing concentration in the overlying water. Although the direct oxidative loss of U could explain the enhanced DOU of sediment $(+24 \%)$, it was assumed that $U$ could influence several microbial-driven diagenetic processes.

Sulfate concentration profiles showed the disappearance of the sulfur oxidation layer in upper sediment and reflected a low diffusion of sulfate from water to sediment and then a lower sulfate reduction rate. In the present case, the microorganisms involved in the sulfur cycle were not stimulated and were even rather inhibited by $\mathrm{U}$ contamination.

In the same manner, there were clear differences in profiles of nitrate/nitrite concentrations between the contaminated and control aquaria. The concentrations in sediment were higher, possibly reflecting intensive nitrification. However, these concentrations might be more probably explained by sediment contamination itself, since uranyl nitrate was used. Nevertheless, this nutrient supply - compared with uncontaminated sediment - seemed not to be consumed by denitrification. Here again, the $\mathrm{U}$ contamination probably did not influence micro-organisms involved in the nitrogen cycle likely more so because they were already not very active in the uncontaminated sediment.

In contrast, $\mathrm{U}$ induced slight modifications of the iron cycle, as indicated by higher concentrations of dissolved iron in bottom sediment due to potentially enhanced dissolutive reduction of $\mathrm{Fe}(\mathrm{III})$ oxi/hydroxides.

Although there was no evidence of strong stimulation by $\mathrm{U}$ of microbial activity linked to sulfur, nitrogen or iron cycles, some examples have been reported previously. Most of these studies have dealt with immobilisation of $U$ in sediment by favouring its reduction in the context of bioremediation of contaminated water. Indeed, U can be a potential substrate for anaerobic respiration (Lovley et al., 1991). Most of the dissimilatory metal-reducing bacteria that can conserve energy by coupling the oxidation of organic matter or hydrogen to the reduction of metallic ions can also reduce $\mathrm{UO}_{2}^{2+}$. Additionally, some sulfate-reducing bacteria can catalyse the reduction of ferrous ions or $\mathrm{UO}_{2}^{2+}$ without obtaining energy or growing with these ions as sole electron acceptors (Wilkins et al., 2006). In contaminated sites, it was demonstrated that anaerobic prokaryotes were easily cultivable on nuclear wastes, with a clear dominance of nitrate-reducing organisms (Akob et al., 2007). In addition to these reduction processes, oxidation of $\mathrm{U}$ (uraninite) can also be biotically favoured in the presence of nitrate or Fe(III) oxides, but it is unknown whether bacteria can obtain energy from this reaction (Borch et al., 2010). Comparatively 
Table 2. Effects of T. tubifex and uranium on sediment biogeochemistry.

\begin{tabular}{|c|c|c|c|}
\hline Parameter & + Tubifex & + Uranium & + Tubifex/uranium \\
\hline \multirow[t]{3}{*}{$\mathrm{O}_{2}$ consumption } & Increased $(+14 \%)^{*}$ & Increased $(+24 \%)^{*}$ & Increased $(+53 \%)^{*}$ \\
\hline & $\begin{array}{l}\text { - higher OM } \\
\text { mineralization }\end{array}$ & $\begin{array}{l}\text { - oxidative loss of } \\
\text { uranium }\end{array}$ & $\begin{array}{l}\text { Combined effects } \\
\text { + OM supply }\end{array}$ \\
\hline & $\begin{array}{l}\text { - oxidation of } \\
\text { removed reduced } \\
\text { compounds }\end{array}$ & $\begin{array}{l}\text { - stimulation of aerobic } \\
\text { micro-organisms (?) }\end{array}$ & \\
\hline Fe cycle & $\begin{array}{l}\text { Increased dissolutive } \\
\text { reduction }\end{array}$ & $\begin{array}{l}\text { Increased dissolutive } \\
\text { reduction }\end{array}$ & $\begin{array}{l}\text { Increased dissolutive } \\
\text { reduction } \\
\text { (no additional effect) }\end{array}$ \\
\hline N cycle & $\begin{array}{l}\text { Higher turnover } \\
\text { Increased denitrification }\end{array}$ & $\begin{array}{l}\text { Slightly increased } \\
\text { nitrification (?) }\end{array}$ & $\begin{array}{l}\text { Increased denitrification } \\
\text { Complex coupling }\end{array}$ \\
\hline S cycle & $\begin{array}{l}\text { Increased sulfate } \\
\text { reduction }\end{array}$ & $\begin{array}{l}\text { Decreased sulfate } \\
\text { reduction }\end{array}$ & $\begin{array}{l}\text { Increased sulfate } \\
\text { reduction }\end{array}$ \\
\hline Water quality & $\begin{array}{l}\text { Increased } \\
{\left[\mathrm{SO}_{4}^{2-}\right] \text { and }\left[\mathrm{NO}_{3}^{-}\right]}\end{array}$ & $\begin{array}{l}\text { Increased } \\
{\left[\mathrm{NO}_{3}^{-}\right],\left[\mathrm{NO}_{2}^{-}\right]} \\
\text {and }[\mathrm{totU}]\end{array}$ & $\begin{array}{l}\text { Increased } \\
{\left[\mathrm{SO}_{4}^{2-}\right],\left[\mathrm{NO}_{3}^{-}\right],\left[\mathrm{NO}_{2}^{-}\right]} \\
\text {and }[\text { totU] }\end{array}$ \\
\hline
\end{tabular}

* From Lagauzère et al. (2009b).

to these studies, the present experiment represents the first assessment of $\mathrm{U}$ contamination on microbial communities not previously exposed to pollution. More generally, toxicity of $\mathrm{U}$ to micro-organisms has been poorly investigated but appears to be lower than for other heavy metals (Nies, 1999). A case of resistance was reported in an aerobic bacterium capable of detoxification through formation and rejection of intra-cytoplasmic granules (Suzuki and Banfield, 2004). Here, we indirectly demonstrated inhibition of activity of micro-organisms involved in the sulfur and nitrogen cycles after some weeks of exposure to contaminated sediment. However, from these results, it is not possible to draw conclusions concerning the long-term effects of such contamination, and potential adaptation processes of micro-organisms cannot be excluded (Hoostal et al., 2008). Finally, in the absence of available estimations of aerobic microbial activity alone, the higher oxygen consumption of sediment in the presence of $U$ should be mainly attributed to its oxidation that led to its increased concentration in the water by solubilisation. Without more evident stimulation of metal reducers, the oxidation of $\mathrm{U}$ may be primarily abiotic.

The presence of T. tubifex worms introduced another transfer pathway of $U$ previously associated with sediment. By conveying particles directly from the depth of maximal ingestion rate $(2 \mathrm{~cm}$ for this $U$ concentration) (Lagauzère et al. 2009a), which is within the reducing zone, to the sediment surface, oxidative dissolution of $U$ was greatly enhanced. In addition, the contact of ingested particles with digestive tract solutions is likely to have contributed to U dissolution. Al- ready observed in marine environments accumulating authigenic U (Zheng et al., 2002), these results confirm previous reports for other metals in freshwater sediments (Krantzberg, 1985; Matisoff, 1995; Ciutat and Boudou, 2003; Ciutat et al., 2007). The flux modelling corresponding to the UT-12 profile indicated that this process was all the more efficient because bioturbation also limited the diffusive flux from water to sediment due to the presence of an oxidation layer in upper sediment. Additionally, a low bioaccumulation of sediment-associated $U$ during the digestive passage of particles in worms favoured its release. Only the bioconcentration factors relative to water were higher than 1 , indicating that diffusion of dissolved $U$ through the tegument of worms may be the dominant way of exposure and accumulation. However, this effect was weak, probably because of water hardness (152 Eq mg $\mathrm{CaCO}_{3} \mathrm{~L}^{-1}$ ) and $\mathrm{pH}$ (8.6) that considerably limited bioavailability of U (Markich, 2002; Sheppard et al., 2006). Nevertheless, long-term effects need to be assessed to determine potential adaptation of worm populations or on the contrary any increased bioaccumulation and toxic effects due to increasing $\mathrm{U}$ concentration in the water.

Although the upward particle advection induced by the worm feeding mode was apparently the most influential factor in the present case, the diagenetic behaviour of metallic pollutants can also be indirectly modified by bioturbationdriven changes in sediment properties (e.g. redox boundaries). In the presence of T. tubifex worms, the DOU of sediment increased by $18 \%$ in comparison with non-bioturbated aquaria (U-0 and U-12) and by $53 \%$ when sediment was 

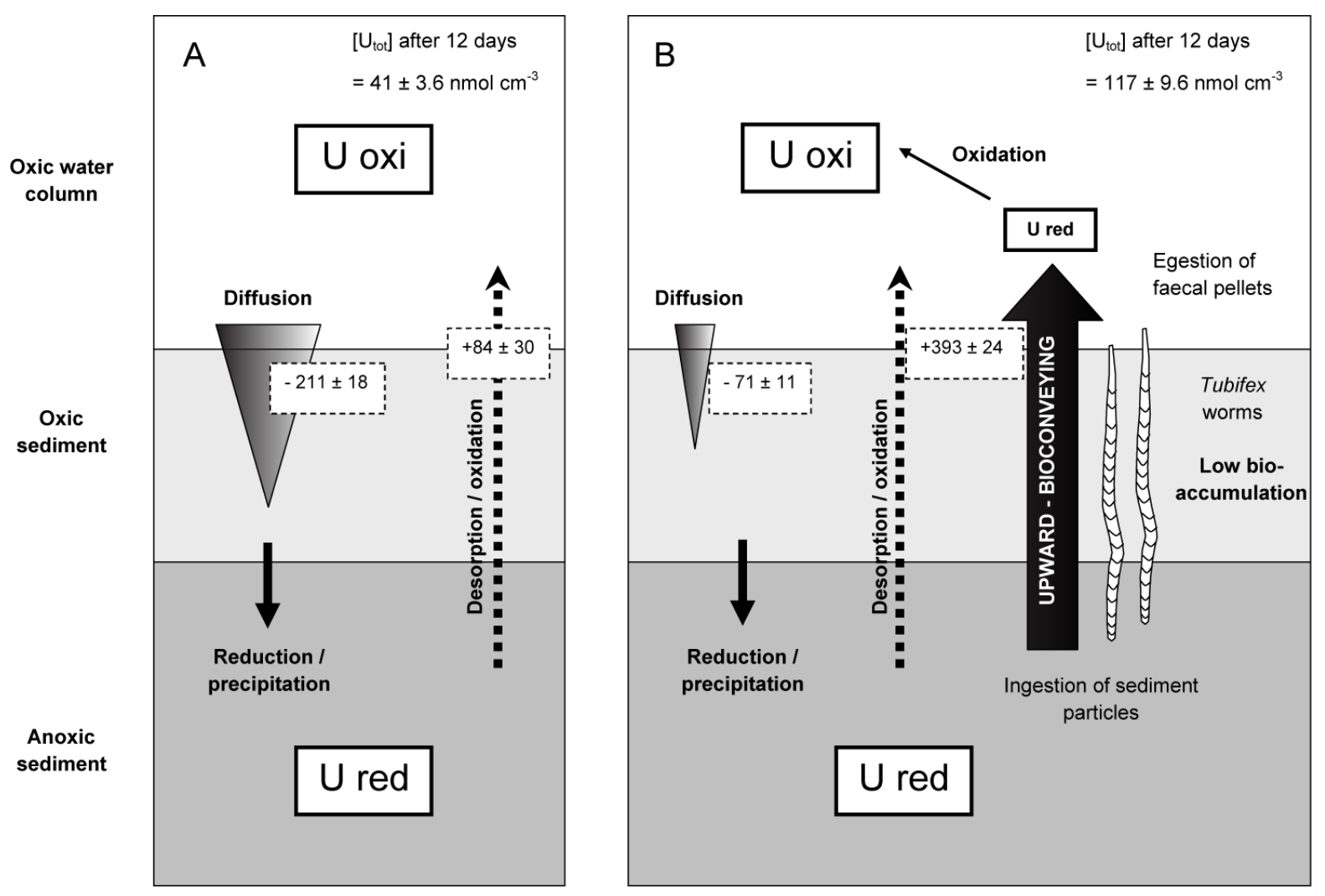

Figure 7. Conceptual outline of the repartition and transfers of U within a sediment without macro-invertebrate (A) or bioturbated by $T$. tubifex worms (B) under an oxygenated water column ( $U$ oxi $=U$ in oxidized form, $U$ red $=U$ in reduced form). Framed values indicate the estimated fluxes of $U$ over the 12 days of experiment $\left(10^{-3} \mathrm{nmol} \mathrm{cm}^{-3} \mathrm{~h}^{-1}\right)$ : diffusion values correspond to diffusive fluxes estimated with PROFILE software; outward flux values, i.e. desorption/oxidation \pm removal by bioturbation, correspond to variation of $U$ concentration in water column in [U-12] and [UT-12] aquaria, respectively.

initially not contaminated (C-0 and C-12) (Lagauzère et al., 2009b). These results suggested that bioturbation stimulated aerobic reactions already favoured by U. However, the present experiment did not totally confirm this hypothesis since anaerobic reactions were mainly stimulated. As for control aquaria, sulfate and nitrate concentrations increased in the water due to modifications in the sediment. The profile of sulfate seemed to result from the combined effect of $\mathrm{U}$ (i.e. inhibition of micro-organisms involved in the sulfur cycle) and bioturbation (i.e. upward-bioconveying of reduced sulfur from bottom sediment, subsequent oxidation in the water and diffusion towards the sediment where it was consumed by sulfate reduction), with the latter apparently dominant. The same trend was observed for nitrate, as the profiles were marked by a negative peak around the interface that could be explained by the use of the nitrate supply due to contamination by uranyl nitrate. Although nitrate was not reduced in the absence of worms (U-0 and U-12), bioturbation seemed to have stimulated denitrification in UT12 aquaria, a reaction which was already slightly enhanced under control conditions (CT-12). It is, however, difficult to explain the increase in nitrate concentration at depth since bioturbation activity decreased at $>2 \mathrm{~cm}$ depth. The occurrence of transient anaerobic nitrification based on ammonium oxidation by manganese oxides, as proposed in the case of newly deposited sediment (i.e. flood sediments or turbidites) in recent studies (Anschutz et al., 2002; Clément et al., 2005; Chaillou et al., 2008) should also be considered. The nitrate profile was particularly complex in contaminated sediment where the interplay with denitrification seems to play an important role. In contrast, the dissolutive reduction of iron oxy/hydroxides did not seem to be modified by the presence of worms.

The higher oxygen consumption of sediment was therefore mainly attributed to oxidation of reduced materials removed from the anoxic bottom sediment. Nevertheless, aerobic microbial respiration could have been stimulated by the higher supply of labile organic matter due to toxic effects on worms themselves (i.e. mortality of $10-20 \%$ of the worm population, enhanced mucous production by resistant individuals and loss of the posterior part of their bodies through a detoxification process).

Finally, after only 12 days of bioturbation, around $5 \%$ of $\mathrm{U}$ initially associated with sediment was removed towards 
the aqueous phase. Based on estimation of diffusive fluxes in the different experimental treatments and $\mathrm{U}$ accumulation in water, a conceptual outline is proposed to visualise the transfers of $U$ in presence of worms in the sediment (Fig. 7). Considering a predicted no-effect concentration (PNEC) of $23 \mathrm{mg} \mathrm{UL}^{-1}$, as estimated from our experimental conditions (pH 8.6 and water hardness $152 \mathrm{Eq} \mathrm{mg} \mathrm{CaCO}_{3} \mathrm{~L}^{-1}$ ), the concentration reached in the water $\left(\sim 30 \mathrm{mg} \mathrm{U} \mathrm{L}^{-1}\right)$ due to bioturbation represents a serious threat to aquatic biota (Sheppard et al., 2006). However, the benthic response to increasing $U$ concentration in the water corresponds to enhanced downward diffusive fluxes. Until a steady state was reached, it would account for increasing bioaccumulation of $U$ and possible toxic effects slowing the bioturbation activity. Additionally, long-term adaptations are likely in a tolerant species such as T. tubifex if some populations are gradually or punctually exposed to $\mathrm{U}$ contamination in the environment.

\section{Conclusions}

This work confirms the major role of T. tubifex bioturbation in the biogeochemistry of freshwater sediments in general (e.g. stimulation of diagenetic processes, remobilisation of reduced materials and redistribution of solutes) and in the remobilisation of $U$ from the sediment. Despite lower bioturbation activity in U-contaminated sediment, these biogeochemical processes were maintained and some microbial communities even stimulated (denitrifying and sulfate-reducing bacterial communities) compared to non-bioturbated sediments (Table 2). It remains unclear if these changes indirectly influenced the U distribution, but $T$. tubifex played a key role in the remobilisation of $U$ from sediment to water through upward-bioconveying of sediment particles. Long-term effects still need to be assessed, microbial diversity and activity have to be investigated more precisely using molecular approaches, and experiments should be extended to real contaminated sites. However, this study provides the first demonstration of biogeochemical modifications induced by bioturbation in freshwater U-contaminated sediment. In regard to the high tolerance of tubificid worms to sediment contamination and the potential risk for aquatic biocenosis exposed to dissolved $\mathrm{U}$, it appears crucial to consider bioturbation as an important factor in further studies, notably in the development of bioremediation strategies where the potential key role of bioturbation has been largely overlooked.

Acknowledgements. This work was supported by the EnvirHom research programme funded by the Institute of Radioprotection and Nuclear Safety (IRSN, France). We wish to thank Virginie Camilleri and Daniel Orjollet for technical assistance with ICP and chromatography. We extend special thanks to Gaëlle Grasset for her great help on sediment mineralisation and bioaccumulation measurements. Thanks also to the three anonymous reviewers whose pertinent comments greatly improved the manuscript.

Edited by: T. Treude

\section{References}

Akob, D. M., Mills, H. J., and Kostka, J. E.: Metabolically active microbial communities in uranium-contaminated subsurface sediments, FEMS Microbiol. Ecol., 59, 95-107, 2007.

Alfaro-De-la-Torre, M. C., and Tessier, A.: Cadmium deposition and mobility in the sediments of an acidic oligotrophic lake, Geochim. Cosmochim. Ac., 66, 3549-3562, 2002.

Anderson, R. F., Fleisher, M. Q., and Lehuray, A. P.: Concentration, oxidation state, and particulate flux of uranium in the Black Sea, Geochim. Cosmochim. Ac., 53, 2215-2224, 1989.

Anschutz, P., Jorissen, F. J., Chaillou, G., Abu-Zied, R., and Fontanier, C.: Recent turbidite deposition in the eastern Atlantic: Early diagenesis and biotic recovery, J. Mar. Res., 60, 835-854, 2002.

Barlett, M., Zhuang, K., Mahadevan, R., and Lovley, D.: Integrative analysis of Geobacter spp. and sulfate-reducing bacteria during uranium bioremediation, Biogeosciences, 9, 1033-1040, doi:10.5194/bg-9-1033-2012, 2012.

Berg, P., Risgaard-Petersen, N., and Rysgaard, S.: Interpretation of measured concentration profiles in sediment pore water, Limnol. Oceanogr., 43, 1500-1510, 1998.

Berner, R. A.: Early Diagenesis: a Theoretical Approach, Princeton University Press, Princeton, USA, 241 pp., 1980.

Borch, T., Kretzschmar, R., Kappler, A., Van Cappellen, P., GinderVogel, M., Voegelin, A., and Campbell, K.: Biogeochemical redox processes and their impact on contaminant dynamics, Environ. Sci. Technol., 44, 15-23, 2010.

Boudreau, B. P.: Diagenetic Models and Their Implementation: Modelling Transport and Reactions in Aquatic Sediments, Springer-Verlag, Berlin, Germany, 1997.

Budd, G. C.: Tubifex tubifex: a Sludge-Worm, Marine Life Information Network: Biology and Sensitivity Key Information Sub-programme (on-line), Marine Biological Association of the UK, Plymouth, available at: www.marlin.ac.uk/species/ Tubifextubifex.htm, 2005.

Chaillou, G., Schäfer, J., Blanc, G., and Anschutz, P.: Mobility of Mo, U, As, and Sb within modern turbidites, Mar. Geol., 254, 171-179, 2008.

Ciutat, A. and Boudou, A.: Bioturbation effects on cadmium and zinc transfers from contaminated sediment and on metal bioavailability to benthic bivalves, Environ. Toxicol. Chem., 22, 1574$1581,2003$.

Ciutat, A., Gerino, M., and Boudou, A.: Remobilization and bioavailability of cadmium from historically contaminated sediments: influence of bioturbation by tubificids, Ecotox. Environ. Safe., 68, 108-117, 2007.

Clément, J.-C., Shrestha, J., Ehrenfeld, J. G., and Jaffé, P. R.: Ammonium oxidation coupled to dissimilatory reduction of iron under anaerobic conditions in wetland soils, Soil Biol. Biochem., 37, 2323-2328, 2005.

Cochran, J. K., Carey, A. E., Sholkovitz, E. R., and Surprenant, L. D.: The geochemistry of uranium and thorium in coastal marine sediments and sediment pore waters, Geochim. Cosmochim. Ac., 50, 663-680, 1986.

Curtis, G. P., Davis, J. A., and Naftz, D. L.: Simulation of reactive transport of uranium(VI) in groundwater with variable chemical conditions, Water Resour. Res., 42, W04404, doi:10.1029/2005WR003979, 2006. 
Davis, J. A., Payne, T. E., and Waite, T. D.: Simulating the $\mathrm{pH}$ and $p \mathrm{CO} 2$ dependence of uranium(VI) adsorption by a weathered schist with surface complexation models, in: Geochemistry of Soil Radionuclides, Special Pub. 59, Soil Science Society America, Madison, WI, 61-86, 2002.

Davis, J. A., Meece, D. E., Kohler, M., and Curtis, G. P.: Approaches to surface complexation modeling of uranium(VI) adsorption on aquifer sediments, Geochim. Cosmochim. Ac., 68, 3621-3641, 2004.

Davis, J. A., Curtis, G. P., Wilkins, M. J., Kohler, M., Fox, P., Naftz, D. L., and Lloyd, J. R.: Processes affecting transport of uranium in a suboxic aquifer, Phys. Chem. Earth, 31, 548-555, 2006.

De Haas, E. M., Kraak, M. H. S., Koelmans, A. A., and Admiraal, W.: The impact of sediment reworking by opportunistic chironomids on specialised mayflies, Freshwater Biol., 50, 770-780, 2005.

Denison, F.: Uranium(VI) Speciation: Modelling, Uncertainty and Relevance to Bioavailability Models. Application to Uranium Uptake by the Gills of a Freshwater Bivalve, Thèse de Doctorat de l'Université Aix-Marseille I., 2004.

Gérino, M., Vervier, P., Stora, G., Gilbert, F., Poggiale, J.-C., François-Carcaillet, F., Mermillod-Blondin, F., and Desrosiers, G.: Macro-invertebrate functional groups in freshwater and marine sediments: a common mechanistic classification, Vie Milieu, 53, 221-232, 2003.

Hart, D. R., McKee, P. M., Burt, A. J., and Goffin, M. J.: Benthic community and sediment quality assessment of Port Hope Harbour, Lake Ontario, J. Great Lakes Res., 12, 206-220, 1986.

Hoostal, M. J., Bidart-Bouzat, M. G., and Bouzat, J. L.: Local adaptation of microbial communities to heavy metal stress in polluted sediments of Lake Erie, FEMS Microbiol. Ecol., 65, 156-168, 2008.

Komlos, J., Peacock, A., Kukkadapu, R. K., and Jaffé, P. R.: Longterm dynamics of uranium reduction/reoxidation under low sulfate conditions, Geochim. Cosmochim. Ac., 72, 3603-3615, 2008.

Krantzberg, G.: The influence of bioturbation on physical, chemical and biological parameters in aquatic environments: a review, Environ. Pollut., 39, 99-122, 1985.

Kurnaz, A., Küçükömeroglu, B., Keser, R., Okumusoglu, N. T., Korkmaz, F., Karahan, G., and Cevik, U.: Determination of radioactivity levels and hazards of soil and sediment samples in Firtina Valley (Rize, Turkey), Appl. Radiat. Isotopes, 65, 1281-1289, 2007.

Lagauzère, S., Boyer, P., Stora, G., and Bonzom, J. M.: Effect of uranium-contaminated sediment on bioturbation activity of Chironomus riparius (Insecta, Diptera) and Tubifex tubifex worms (Annelida, Tubificidae), Chemosphere, 76, 324-334, 2009a.

Lagauzère, S., Pischedda, L., Cuny, P., Gilbert, F., Stora, G., and Bonzom, J. M.: Influence of Chironomus riparius (Diptera, Chironomidae) and Tubifex tubifex (Oligochaeta, Tubificidae) on oxygen uptake by sediments. Consequences of uranium contamination, Environ. Pollut., 157, 1234-1242, 2009b.

Lagauzère, S., Terrail, R., and Bonzom, J. M.: Ecotoxicity of uranium on Tubifex tubifex (Annelida, Tubificidae) exposed to contaminated sediment, Ecotox. Environ. Safe., 72, 527-537, 2009c.

Langmuir, D.: Uranium solution-mineral equilibria at low temperatures with applications to sedimentary ore deposits, Geochim. Cosmochim. Ac., 42, 547-596, 1978.
Li, Y. and Gregory, S.: Diffusion of ions in sea water and in deep-sea sediments, Geochim. Cosmochim. Ac., 38, 703-714, 1974.

Liger, E., Charlet, L., and Van Cappellen, P.: Surface catalysis of uranium(VI) reduction by iron(II), Geochim. Cosmochim. Ac., 63, 2939-2955, 1999.

Lottermoser, B. G. and Ashley, P. M.: Physical dispersion of radioactive mine waste at the rehabilitated Radium Hill uranium mine site, South Australia, Aust. J. Earth Sci., 53, 485-499, 2006.

Lovley, D. R., Phillips, E. J. P., Gorby, Y. A., and Landa, E. R.: Microbial reduction of uranium, Nature, 350, 413-416, 1991.

Lozano, J. C., Blanco Rodríguez, P., and Vera Tomé, F.: Distribution of long-lived radionuclides of the $238 \mathrm{U}$ series in the sediments of a small river in a uranium mineralized region of Spain, J. Environ. Radioactiv., 63, 153-171, 2002.

Marang, L.: Influence de la Matière Organique Naturelle Sur la Spéciation des Radionucléides en Contexte Géochimique, Ph.D. thesis, University Paris Diderot-Paris 7 and IPGP, 178 pp., 2007.

Markich, S. J.: Uranium speciation and bioavailability in aquatic systems: an overview, Scientific World Journal, 2, 707-729, 2002.

Matisoff, G.: Effects of bioturbation on solute and particle transport in sediments, in: Metal Contaminated Aquatic Sediments, edited by: Allen, H. E., Ann Arbor Press, Chelsea, MI, 201-272, 1995.

Mc Call, P. L. and Fisher, J. B.: Effects of tubificid oligochaetes on physical and chemical properties of Lake Erie sediments, in: Aquatic Oligochaete Biology, edited by: Brinkhurt, R. O. and Cook, D. G., Plenum Press, New York, 253-317, 1980.

Mermillod-Blondin, F., Nogaro, G., Datry, T., Malard, F., and Gibert, J.: Do tubificid worms influence the fate of organic matter and pollutants in stormwater sediments?, Environ. Pollut., 134, 57-69, 2005.

Mermillod-Blondin, F., Foulquier, A., Gilbert, F., Navel, S., Montuelle, B., Bellvert, F., Comte, G., Grossi, V., Fourel, F., Lecuyer, C., and Simon, L.: Benzo(a)pyrene inhibits the role of the bioturbator Tubifex tubifex in river sediment biogeochemistry, Sci. Total. Environ., 450-451, 230-241, 2013.

Morford, J. L., Martin, W. R., and Carney, C. M.: Uranium diagenesis in sediments underlying bottom waters with high oxygen content, Geochim. Cosmochim. Ac., 73, 2920-2937, 2009.

Motelica-Heino, M., Naylor, C., Zhang, H., and Davison, W.: Simultaneous release of metals and sulfide in lacustrine sediment, Environ. Sci. Technol., 37, 4374-4381, 2003.

Naylor, C., Davison, W., Motelica-Heino, M., Van Den Berg, G. A., and Van Der Heijdt, L. M.: Simultaneous release of sulfide with $\mathrm{Fe}, \mathrm{Mn}, \mathrm{Ni}$ and $\mathrm{Zn}$ in marine harbour sediment measured using a combined metal/sulfide DGT probe, Sci. Total. Environ., 328, 275-286, 2004.

Naylor, C., Davison, W., Motelica-Heino, M., Van Den Berg, G. A., and Van Der Heijdt, L. M.: Potential kinetic availability of metals in sulphidic freshwater sediments, Sci. Total. Environ., 357, 208220, 2006.

Naylor, C., Davison, W., Motelica-Heino, M., Heijdt, L. M., and den Berg, G. A.: Transient release of Ni, Mn and Fe from mixed metal sulphides under oxidising and reducing conditions, Environ. Earth Sci., 65, 2139-2146, 2012.

Neame, P. A., Dean, J. R., and Zytaruk, B. G.: Distribution and concentrations of naturally occurring radionuclides in sediments in a uranium mining area of northern Saskatchewan, Canada, Hydrobiologia, 91-92, 355-361, 1982. 
Nies, D. H.: Microbial heavy-metal resistance, Appl. Microbiol. Biot., 51, 730-750, 1999.

Nogaro, G., Mermillod-Blondin, F., Montuelle, B., Boisson, J. C., Lafont, M., Volat, B., and Gibert, J.: Do tubificid worms influence organic matter processing and fate of pollutants in stormwater sediments deposited at the surface of infiltration systems?, Chemosphere, 70, 315-328, 2007.

Pelegri, S. P. and Blackburn, T. H.: Effects of Tubifex tubifex (Oligochaeta: Tubificidae) on $\mathrm{N}$ mineralization in freshwater sediments, measured with $15 \mathrm{~N}$ isotopes, Aquat. Microb. Ecol., 9, 289-294, 1995.

Petersen, W., Wallmann, K., Pinglin, L., Schroeder, F., and Knauth, H.-D.: Exchange of trace elements at the sediment-water interface during early diagenesis processes, Mar. Freshwater Res., 46, 19-26, 1995.

Phrommavanh, V.: Etude de la Migration de l'Uranium en Milieu Naturel: Approche Experimentale et Modélisation Géochimique, Ph.D thesis, University Joseph Fourier-Grenoble 1, 222 pp., 2008.

Ragnarsdottir, K. V. and Charlet, L.: Uranium behaviour in natural environments, in: Environmental Mineralogy Microbial Interactions. Anthropogenic influences. Contaminated Land and Waste Management, Mineralogical Society of Great Britain and Ireland, 333-377, 2000.

Renshaw, J. C., Lloyd, J. R., and Livens, F. R.: Microbial interactions with actinides and long lived fission products, C.R. Chim., 10, 1067-1077, 2007.
Schultz, H. D. and Zabel, M.: Marine Geochemistry, Springer, Berlin, New York, 455 pp., 2000.

Sheppard, S. C., Sheppard, M. I., Tait, J. C., and Sanipelli, B. L.: Revision and meta-analysis of selected biosphere parameter values for chlorine, iodine, neptunium, radium, radon and uranium, J. Environ. Radioactiv., 89, 115-137, 2006.

Soster, F. M., Harvey, D. T., Troksa, M. R., and Grooms, T.: The effect of Tubificid oligochaetes on the uptake of zinc by Lake Erie sediments, Hydrobiologia, 248, 249-258, 1992.

Suzuki, Y. and Banfield, J. F.: Resistance to, and accumulation of, uranium by bacteria from a uranium-contaminated site, Geomicrobiol. J., 21, 113-121, 2004.

Svensson, J. M., Enrich-Prast, A., and Leonardson, L.: Nitrification and denitrification in a eutrophic lake sediment bioturbated by oligochaetes, Aquat. Microb. Ecol., 23, 177-186, 2001.

Wilkins, M. J., Livens, F. R., Vaughan, D. J., and Lloyd, J. R.: The impact of $\mathrm{Fe}(\mathrm{III})$-reducing bacteria on uranium mobility, Biogeochemistry, 78, 125-150, 2006.

Zheng, Y., Anderson, R., Van Geen, A., and Fleisher, M.: Remobilization of authigenic uranium in marine sediments by bioturbation, Geochim. Cosmochim. Ac., 66, 1759-1772, 2002.

Zoumis, T., Schmidt, A., Grigorova, L., and Calmano, W.: Contaminants in sediments: remobilisation and demobilisation, Sci. Total. Environ., 266, 195-202, 2001. 